\title{
INSTITUCIJSKI OKVIR UPRAVLJANJA JAVNIM DUGOM U EUROPSKOJ UNIJI S OSVRTOM NA HRVATSKU ${ }^{3}$
}

\begin{abstract}
SAŽETAK
Upravljanje javnim dugom već dugo vremena ima važnu ulogu na tržištu kapitala, a uvođenje eura i financijska kriza pojačali su ulogu institucija za upravljanje javnim dugom. Cilj rada je pokazati važnost institucijskog okvira i organizacije uprava za javni dug za kvalitetu upravljanja javnim dugom. U Europi se pojačava svijest kako je potrebno što je moguće više osamostaliti institucije za upravljanje javnim dugom kako bi se osigurala profesionalnost u upravljanju izuzetno velikim državnim obvezama, što je posebno važno u razdobljima krize. Upravljanje javnim dugom važno je i za financijsku stabilnost, a institucijski status treba uzeti u obzir važne čimbenike upravljanja javnim dugom, kao što su ciljevi upravljanja javnim dugom, organizacija, nositelji duga, izdavatelji duga i prakse trgovanja dugom. Ovaj rad prvenstveno analizira institucijski okvir upravljanja javnim dugom. Koncept analize zasniva se na usporedbi institucijskih okvira u zemljama Europske unije. Dužničke krize i globalna financijska kriza naglasile su važnost profesionalnog upravljanja javnim dugom koje se najbolje može ostvariti osnivanjem neovisne institucije za upravljanje javnim dugom. Kreatori ekonomske politike nisu uvijek spremni na reformu i poboljšanje upravljanja javnim dugom dok se ne pojavi kriza ili dug postane neodrživ. U radu se zaključuje kako je izbor neovisne institucije za upravljanje javnim dugom najbolji način za uspješno upravljanje javnim dugom.
\end{abstract}

Ključne riječi: jauni dug, dužnička kriza, tržište kapitala

\section{UVOD I PREGLED LITERATURE}

Mnoge su se europske zemlje u protekla dva desetljeća suočavale s problemom efikasnog upravljanja javnim dugom, koji su najčešće riješile osnivanjem posebnih institucija za upravljanje javnim dugom. Naime, to je bio način da se poboljša upravljanje javnim dugom uz pomoć visokokvalificiranih stručnjaka, te da se optimizira trošak servisiranja javnog duga i da se proces upravljanja javnim dugom učini transparentnijim.

U razdoblju velike volatilnosti na financijskim tržištima nakon globalne financijske krize jača svijest nositelja fiskalne politike o tome da je potrebno smanjiti ranjivost na financijske šokove, stoga je

Dr. sc., viši predavač, Hrvatska narodna banka, Trg hrvatskih velikana 3, 10000 Zagreb, Hrvatska.

E-mail: ante.zigman@hnb.hr

2 Dr. sc., viši znanstveni suradnik, Croatia banka d. d., R. F. Mihanovića 9, 10000 Zagreb, Hrvatska.

E-mail: ivan.sverko@croatiabanka.hr

3 Datum primitka rada: 9. 12. 2016.; datum prihvaćanja rada: 15. 2. 2017. 
logično postaviti pitanje je li potrebno osnovati odvojenu upravu za upravljanje javnim dugom koja bi učinkovitije upravljala javnim dugom. Jedan dio europskih zemalja (njih 11 od 28) potpuno je izdvojio uprave za upravljanje javnim dugom izvan ministarstva financija kroz osnivanje agencija. Velik broj zemalja još uvijek ima upravljanje javnim dugom unutar riznice ministarstva financija, ali uz određenu razinu autonomije koja omogućuje zapošljavanje i zadržavanje visokokvalificiranih kadrova.

Kada u nekoj agenciji postoji operativna neovisnost upravljanja javnim dugom, nužno je da Ministarstvo financija i sama agencija za upravljanje javnim dugom imaju nedvosmislenu i jasnu strategiju upravljanja javnim dugom, zatim indikatore uspješnosti rada agencije te strog nadzor i upravljačke kontrolne funkcije. Srednjoročna strategija upravljanja javnim dugom bi trebala obuhvaćati razdoblje od četiri godine unaprijed i svake se godine ažurirati. Zatim je nužna koordinacija makroekonomskih politika, a zaduženja države trebaju biti povezana s financijskim aktivnostima države, upravljanje novčanim tijekom i raspoloživim sredstvima na računu, upravljanje operativnim rizicima i, na kraju, transparentnost treba iskazati kroz statistiku javnog duga i izvješćivanje.

Važnost upravljanja javnim dugom ne odnosi se samo na fiskalnu politiku, već ima presudan utjecaj na financijsku stabilnost u dugom roku. Institucije za upravljanje javnim dugom svojim aktivnostima kreiraju važna očekivanja na tržištu obveznica, pa je za uspješno upravljanje javnim dugom važna njihova stručnost i kvaliteta.

U prvom dijelu bit će opisan pregled literature, zatim institucijske implikacije upravljanja javnim dugom, nadalje je opisano upravljanje agencijama za javni dug, implikacije za manje razvijene zemlje, opće preporuke za upravljanje javnim dugom, zatim osvrt na Hrvatsku i na kraju zaključak.

Institucijskim okvirom za upravljanje javnim dugom već se dulje vrijeme bave Međunarodni monetarni fond i Svjetska banka koji suobjavili „Vodič za upravljanje javnim dugom” i njegovu reviziju (IMF, 2014). Taj je dokument važan za sve one institucije koje upravljaju javnim dugom jer osiguravaju ujednačavanje standarda rada. Ujednačavanje standarda rada institucija za upravljanje javnim dugom važno je za sve sudionike na tržištu kapitala, odnosno, i za investitore koji žele imati ujednačenu praksu u onim državama u koje investiraju. Vodič MMF-a i Svjetske banke predstavlja se na velikim konferencijama na kojima sudjeluju i investitori i izdavatelji i time se postiže potpuna transparentnost i uključenost tržišta. Za uspjeh rada institucije za upravljanje javnim dugom izuzetno je važno da postoji kontinuirana komunikacija između izdavatelja duga (država) i kupaca koje u najvećem broj predstavljaju banke.

Analizu zemalja OECD-a napravila je grupa autora (Currie, Dethier, Togo, 2003) koja je analizirala institucijska uređenja upravljanja javnim dugom. Ovaj rad posebno se bavi odnosom principala - agenta koji proizlazi iz delegiranja ovlasti Ministarstva financija na agenciju za upravljanje javim dugom. Ovaj rad zanimljiv je jer opisuje kako su pojedine države uredile sustav nadzora i kontrole nad izdvojenim institucijama.

Isti rad dokazao je da je u 60-im i 70-im godinama postojala snažna veza između upravljanja javnim dugom i monetarne politike. Naime, do 80 -ih godina javni dug se smatrao produžetkom 
monetarne politike. Kako su rastući deficiti i javni dug u zemljama Europske unije 70-ih godina utjecali na rast inflacije, sve je više rasla svijest o tome da je potrebno razdvojiti izdavanje javnog duga i inflaciju. Naime, centralne banke su 70-ih morale birati između financiranja deficita i rasta javnog duga i inflacije. Ako dugoročna financijska održivost postaje problem da je potrebno ograničiti rast javnog duga, a centralna banka jedino može pridonijeti financiranju deficita kroz seniorage. Stoga, ako bi centralna banka prestala financirati deficit, prekinula bi se veza između visokog javnog duga i inflacije, a vlada bi bila prisiljena riješiti problem kroz strukturne reforme i smanjenje deficita.

Nakon uvođenja eura i uklanjanja tečajnog rizika počeo je ubrzani razvoj europskog tržišta duga na kojem su institucije za upravljanje javnim dugom postale izravna konkurencija sudionicima na europskom tržištu kapitala (Wolswijk, de Haan, 2005). Autori su analizirali ključne čimbenike upravljanja javnim dugom: ciljeve upravljanja javnim dugom, organizaciju, dospijeće duga, nositelje duga, izdavatelje duga i prakse trgovanja dugom.

Odnosi među upravljanjem javnim dugom te monetarnom i fiskalnom politikom analizirani su (Togo, 2007) tako da se pokazuju posljedice nekoordinirane politike. Visoka razina državnih obveza kreirala je državne odluke bez presedana početkom financijske krize (Weist, Togo, Prased, O’Boyle, 2010). Upravljanje javnim dugom poseban je problem za ekonomije s nižim dohotkom koje su zbog financijske krize morale odgoditi reforme institucija za upravljanje javnim dugom.

Zanimljiva je slučajnost da je MMF upravo godinu dana prije financijske krize objavio izvješće o jačanju upravljanja javnim dugom kroz slučajeve pojedinih zemalja (IMF, WB, 2007).

Domaći autori objavili su rad o upravljanju javnim dugom prije, poslije i nakon krize na primjeru triju zemalja EU-a koje su nakon toga uspoređene sa situacijom u Hrvatskoj (Švaljek, Andabaka Badurina, 2011). Osim toga postoji interesantan rad o koordinaciji upravljanja javnim dugom i vođenjem monetarne politike u Hrvatskoj. Navedeni članak objavljen je još 2007. godine te je naročitu pažnju posvetio korištenju operacija na otvorenom tržištu i njihovom utjecaju na upravljanje javnim dugom (Raspudić Golomejić, 2007). Konačno, 2012. godine objavljen je i rad koji je analizirao i uspoređivao osnovne ciljeve upravljanja javnim dugom u Republici Hrvatskoj i u zemljama istočne Europe (Bajo, Pezer, 2012).

\section{KONCEPCIJA UPRAVLJANJA INSTITUCIJAMA ZA JAVNI DUG}

U ovom poglavlju opisuju se problemi koji rezultiraju prelaskom uprava za upravljanje javnim dugom iz Ministarstva financija u neovisne agencije (neovisne institucije), te se opisuju osnove organizacijske strukture i kontrolni mehanizmi nad izdvojenim uredima za upravljanje javnim dugom. Naime, svako izdvajanje organizacijske jedinice iz neke državne institucije povećava rizike, stoga način rada i kontrolni mehanizmi moraju biti detaljno specificirani.

Bez obzira na lokaciju upravljanja javnim dugom Ministarstvo financijama je u konačnici odgovorno za zaduživanje države i za odobravanje strategije upravljanja javnim dugom, dok se operativna odgovornost za svakodnevne poslove oko upravljanja javnim dugom delegira upravi/agenciji za upravljanje javnim dugom. Delegiranje sa sobom povlači tzv. principal-agent problem jer u situaciji gdje 


\section{A. Žigman, I. Šverko: Institucijski okvir upravljanja javnim dugom u Europskoj uniji s osvrtom... Zbornik Veleučilišta u Rijeci, Vol. 5 (2017), No. 1, pp. 33-44}

postoji asimetričnost informacija postoji mogućnost pojave moralnog hazarda, budući da principal (Ministarstvo) ne verificira aktivnosti agenta (Agencije). Drugim riječima, Ministarstvo ne može razlučiti je li prije definirani mandat dan Agenciji dostignut s obzirom na nesposobnost Agencije ili zbog objektivnih uvjeta na tržištu koji nisu pod kontrolom Agencije. Primjerice, ako je Agencija imala mandat da napravi bolji rezultat od benchmarka i ako to nije uspjela, nejasno je je li cilj neispunjen zbog lošeg upravljanja ili zbog loše tržišne situacije koja nije bila pod kontrolom Agencije.

Uz sve navedeno postoje još dva izvora moralnog hazarda. Prvi se odnosi na stvaranje potencijalnih obveza koje mogu utjecati na to da naknadno stvore obvezu za državni proračun. Drugi se odnosi na mogućnost Agencije koja upravlja javnim dugom da trguje na domaćem tržištu i time utječe na smjer tržišta, te utječe na benchmark portfelja kojim upravlja.

Stoga je potrebno uzeti u obzir pet točaka kako bi se organizirala upravljačka struktura za upravljanje javnim dugom:

1. Agencija/Uprava za upravljanje javnim dugom mora biti razvrstana kao subjekt koji ulazi u konsolidaciju s državom i ima jasne odgovornosti;

2. Ciljevi upravljanja javnim dugom moraju biti jasno određeni, razrađeni kroz strateške ciljeve, te ako se aktivno trguje dugom moraju biti određeni pokazatelji učinka (engl. perfeormance benchmarking).

3. Djelatnici koji upravljaju javnim dugom moraju imati ugovore o radu koji su poticajni kako bi se osiguralo da djelatnici budu vrhunski stručnjaci, te da se osigura kontinuirani napor u postizanju zacrtanih ciljeva;

4. Poslovi Agencije/Uprave moraju biti stalno pod nadzorom i uspostavljene kontrolne funkcije;

5. Ministarstvo koje najčešće nadzire rad takvih institucija, treba imati kapacitet za obavljanje nadzorne funkcije.

Tamo gdje je funkcija upravljanja dugom raspršena po različitim institucijama ili odjelima, teško je organizirati upravljanje javnim dugom sa strateške razine. Stoga je važno da se funkcije upravljanja dugom konsolidiraju u jedan ured koji je formalno osnovan i ima formalan status/ identitet s jasno određenim voditeljem, tako da se odgovornost i ovlasti mogu delegirati. Stupanj formalnosti u uspostavljanju ureda za upravljanje javnim dugom kao agencije ovisi o tome je li upravljanje javnim dugom unutar Ministarstva financija ili izvan njega. U slučaju kada su te ovlasti izvan Ministarstva obično se osnivaju statutima koji definiraju njihov pravni status, odgovornost, nadzor i organizaciju. Kada je ovlast upravljanja javnim dugom unutar Ministarstva financija tada se obično osniva odlukom ministra bez posebnog pravnog statusa, ali u odluci su jasno navedene njihove odgovornosti, nadzor i organizacija.

Postoje tri osnovna institucijska rješenja upravljanja javnim dugom: (i) upravljanje javnim dugom u ministarstvu financija, (ii) centralnoj banci ili (iii) u zasebnim agencijama za upravljanje javnim dugom.

Rastući javni dug popraćen postkriznim razdobljem pojačava potrebu za sve većom neovisnošću ciljeva i prioriteta upravljanja javnim dugom. Takva situacija djelovala je i na izbor institucijskog uređenja 
upravljanja javnim dugom. Hrvatska se od 2013. našla u sasvim novom ekonomsko-političkom okruženju koje traži da se učini mnogo na planu fiskalne održivosti i održivosti javnog duga.

Empirijski dokazi podržavaju činjenicu da su snažne institucije za upravljanje javnim dugom i jasne politike, te nedvosmisleni ciljevi upravljanja javnim dugom odigrali ključnu ulogu u amortiziranju efekata financijske krize. Postojala je pozitivna reakcija nositelja ekonomske politike koja je vodila prema smanjenju rizika u portfelju u godinama prije nego je došlo do krize. Primjerice, zemlje u kojima postoje snažnije institucije za upravljanje javnim dugom oslanjale su se više na dugoročna zaduženja i na međunarodne financijske institucije koje se ne povlače čim se u zemlji pojavi kriza. Naime, u manje razvijenim ekonomijama nedostatak ekonomske diverzifikacije te plitko financijsko tržište čine ih posebno osjetljivim na eksterne šokove. Pri tome je nizak njihov institucijski i ljudski kapacitet da pravovremeno i ispravno reagiraju na krizu. (Weist, Togo, Prased, O'Boyle, 2010)

\section{ANALIZA UPRAVLJANJA JAVNIM DUGOM}

Za kvalitetno upravljanje javnim dugom ključno je da su jasno definirani ciljevi koji pokazuju i razinu sklonosti države prema riziku. Preferencija države prema riziku održava mandat koji je Ministar financija dobio od Parlamenta i koji bi trebao održavati srednju vrijednost sklonosti birača riziku (Currie, Dethier, Togo, 2003).

\section{Tablica 1. Ciljevi upravljanja javnim dugom u pojedinim zemljama}

\begin{tabular}{|c|c|}
\hline Belgija & $\begin{array}{l}\text { Glavni cilj je smanjiti financijske troškove koji se odnose na javni dug uzimajući u obzir } \\
\text { tržišne i operativne rizike u skladu s općim ciljevima fiskalne i monetarne politike. }\end{array}$ \\
\hline Danska & $\begin{array}{l}\text { Cjelokupan cilj politike upravljanja javnim dugom je postići najniže moguće dugoročne } \\
\text { troškove financiranja, uzimajući u obzir: } \\
\text { - održavanje rizika na prihvatljivoj razini } \\
\text { - } \quad \text { podršku i razvoj cjelokupnog financijskog tržišta u Danskoj } \\
\text { - } \quad \text { olakšanje pristupa države financijskim tržištima u dugom roku. }\end{array}$ \\
\hline Irska & $\begin{array}{l}\text { Glavni cilj je financiranje dospjelog duga i godišnjih potreba za financiranjem države } \\
\text { tako da se osigura kratkoročna i dugoročna likvidnost, smanjujući razinu i volatilnost } \\
\text { troškova zaduživanja te držanja pod kontrolom izloženost države rizicima i biti bolji od } \\
\text { benchmarka. }\end{array}$ \\
\hline Portugal & $\begin{array}{l}\text { Cilj je financiranje i obavljanje drugih financijskih transakcija u ime države, tako da se: } \\
\text { - ispune potrebe za financiranjem na stabilan način; } \\
\text { - minimiziraju troškovi financiranja državnog duga u dugom roku u skladu sa } \\
\text { strategijom rizika koju je odredila Vlada; } \\
\text { aktivnosti zasnivaju na principima efikasnosti i transparentnosti. }\end{array}$ \\
\hline Švedska & $\begin{array}{l}\text { Cilj upravljanja javnim dugom je na dugoročnoj razini minimizirati troškove javnog duga } \\
\text { s brigom o rizicima povezanim s upravljanjem javnim dugom. No upravljanje javnim } \\
\text { dugom mora uvijek biti povezano s okvirom potreba i zahtjeva nositelja monetarne } \\
\text { politike i smjernicama Vijeća ministara. }\end{array}$ \\
\hline
\end{tabular}

Izvor: Currie, Dethier, Togo (2003) 
Kada se definira jasan skup ciljeva, oni se moraju prevesti u primjenjivu strategiju upravljanja javnim dugom u terminima strateških ciljeva. Analiza rada institucija za upravljanje javnim dugom daje niz mogućih ciljeva koji se mogu predložiti u strategiji. Kada se ciljevi predlože, tada institucija za upravljanje javnim dugom preuzima potpunu odgovornost za implementaciju strategije upravljanja javnim dugom.

Javna objava strategije jača transparentnost i odgovornost institucije zadužene za upravljanje javnim dugom. Primjerice, Švedska u cilju povećanja odgovornosti upravljanja javnim dugom određuje ciljeve na razini Parlamenta. Ciljevi su javno objavljeni, što povećava transparentnost i predvidljivost omogućujući instituciji za upravljanje javnim dugom da se usmjeri na zadatke i stvaranje rezultata.

Tablica 2. Objavljeni strateški ciljevi za pojedine zemlje EU-a

\begin{tabular}{|c|c|c|c|c|c|}
\hline Zemlja (objava) & $\begin{array}{c}\text { Javni dug } \\
\text { (\% BDP-a) }\end{array}$ & $\begin{array}{c}\text { Prosječno } \\
\text { dospijeće duga }\end{array}$ & Refinanciranje & $\begin{array}{c}\text { Valutna } \\
\text { struktura } \\
\text { Domaći : } \\
\text { inozemni }\end{array}$ & $\begin{array}{c}\text { Kamatna } \\
\text { stopa (u \%) }\end{array}$ \\
\hline Belgija (12. 2013.) & $101,5 \%$ & $7,5-7,8$ godina & $\begin{array}{c}60 \text { mjeseci limit na } \\
60 \%\end{array}$ & $97: 3$ & $4 \pm 0,30$ \\
\hline $\begin{array}{c}\text { Danska } \\
(6.2014 .)\end{array}$ & $44,9 \%$ & 8 godina & $\begin{array}{c}\text { Poboljšati profil } \\
\text { otplate javnog } \\
\text { duga }\end{array}$ & $88: 12$ & $3,5 \pm 0,5$ \\
\hline $\begin{array}{c}\text { Francuska } \\
(12.2001 .)\end{array}$ & $96,6 \%$ & 5,5 godina & $\begin{array}{c}\text { Održati prosječno } \\
\text { dospijeće iznad 5,5 } \\
\text { godina }\end{array}$ & $100: 0$ & - \\
\hline $\begin{array}{c}\text { Portugal } \\
(12.2013 .)\end{array}$ & $124,8 \%$ & 5 godina & $\begin{array}{c}\text { Izbjegavati velike } \\
\text { potrebe za } \\
\text { refinanciranjem }\end{array}$ & $100: 0$ & 3,0 \\
\hline
\end{tabular}

Izvor: Web-mjesta institucija za javni dug (www.debtagency.be http://www.nationalbanken.dk/en/governmentdebt http://www.aft.gouv.fr/ https://www.igcp.pt/pt/)

U institucijama u kojima se aktivno trguje javnim dugom, strateški ciljevi prevode se u pokazatelje učinka. Tako se trgovanje dugom provodi prema pokazateljima učinka koji omogućuje da nadzorno tijelo mjeri učinak menadžera javnim dugom, te ih se time smatra odgovornima za njihove radnje. Austrija, Švedska, Danska, Irska i Portugal provode aktivno trgovanje i mjerenje učinka trgovanja. Menadžeri javnim dugom uglavnom ne provode trgovanje na domaćem tržištu, već uglavnom na inozemnom tržištu gdje država nije kreator cijene i gdje menadžeri javnim dugom ne mogu utjecati na pokazatelje učinka.

Akcije institucija koje upravljaju javnim dugom moraju biti nadzirane i kontrolirane. Što više je upravljanje javnim dugom udaljeno od ministarstva, to je više potrebno utvrditi formalne kanale kontrole i nadzora kako bi se smanjio rizik. Nadzorne i kontrolne funkcije mogu se provesti kroz uspostavu neovisnog odjela koji bi onemogućavao da front office manipulira s informacijama iz 
back officea. Nadzorna i kontrolna funkcija može se uspostaviti i kroz Upravna vijeća koja imaju odgovornost da nadziru, potvrđuju i sankcioniraju odluke institucije koja upravlja javnim dugom. Uz vanjski nadzor, institucija za upravljanje javnim dugom mora imati i vlastiti sustav nadzorna i kontrole te kontinuirani sustav izvješćivanja prema ministarstvu financija, a jednom godišnje i prema Parlamentu i prema javnosti.

Irska, Švedska i Danska devedesetih godina odlučile su izdvojiti uprave za javni dug izvan Ministarstva financija te su u njima zaposlile vrhunske financijske stručnjake koji imaju iskustva u portfolio menadžmentu. Treba naglasiti da se stručnost voditelja tih Agencija (Švedska, Irska, Danska) i danas vidi na sastancima pododbora Europskog vijeća za javni dug (ESDM).

U Irskoj je na osnovi preporuka iz privatnog sektora i bankarskih konzultanata osnovano tijelo za upravljanje javnim dugom izvan Ministarstva financija kroz poseban zakon koji je usvojen 1990. godine. Zakon navodi da je NTMA (engl. National Treasury Management Agency) osnovan jer je upravljanje javnim dugom postalo izuzetno složena i visokosofisticirana aktivnost koja traži fleksibilnu upravljačku strukturu i prikladno kvalificirane djelatnike koji će biti u mogućnosti pronaći potencijale za uštede. Također je utvrđeno da će organizacija koja se upravlja kao i komercijalne institucije i sa slobodom da zaposli iskusne djelatnike pokazati više profesionalizma nego što bi to bilo moguće unutar ograničenja koje nameće državna administracija. Irska je praktički bila jedina zemlja koja je imala izdvojeno upravljanje javnim dugom od Ministarstva financija i aktivno trgovala/upravljala domaćim dugom u odnosu na performance benchmark.

Švedska ima dugu povijest upravljanja javnim dugom izvan Ministarstva financija. Danska je 1991. odlučila prebaciti ured za upravljanje javnim dugom iz Ministarstva financija u centralnu banku, ali je za to vrijeme zaduživanje ostalo pod Ministarstvom financija. Odluka o izdvajanju upravljanja javnim dugom iz Ministarstva financija u centralnu banku slijedila je nakon izvješća glavnog državnog revizora koje je pokazalo da većina poslova koji se odnose na upravljanje javnim dugom već obavlja u centralnoj banci te da bi tješnja koordinacija između upravljanja deviznim rezervama i deviznom komponentom javnog duga bila poželjna. U izvješću državnog revizora također se navodi da će dovođenja i zadržavanje kadrova s relevantnim vještinama za upravljanje javnim dugom biti jednostavnije ako će posao upravljanja javnim dugom biti locirano u centralnoj banci. Kao rezultat Danska centralna banka postala je odgovorna za sve funkcije vezane za upravljanje javnim dugom, a podjela odgovornosti navedena je u sporazumu između Ministarstva financija i centralne banke. Treba istaknuti da je ovo jedinstven slučaj da centralna banka upravlja javnim dugom.

Tijekom posljednjeg desetljeća prošlog stoljeća mnoge zemlje slijedile su primjer Irske, Danske i Švedske, te su izdvojile svoje uprave za upravljanje javnim dugom iz Ministarstva financija u zasebnu agenciju. Među te zemlje spadaju: Portugal, Austrija i Mađarska. Da su to najbolje prakse potvrđuju i drugi istraživački radovi u kojima su zemlje kao što su Nizozemska, Irska i Mađarska uzete kao ogledni primjeri upravljanja javnim dugom u EU-u (Švaljek, Andabaka Badurina, 2011).

Kvaliteta upravljanja dugom u najvećem broju slučajeva ovisi o tome jesu li ciljevi upravljanja dugom jasno definirani i koordinirani sa svim sudionicima u procesu. U praksi je često organizacijska disperziranost posljedica nedostatka i dosljedne primjene cilja i misije upravljanja javnim dugom. Često se pojavljuje i rivalitet između raznih organizacijskih dijelova, a disperzija implicira operativni 
rizik, što je posljedica nedostatka strateškog pristupa prema riziku. Stoga u nekim zemljama nije niti uspjela reforma upravljanja javnim dugom jer je nedostajao jasan cilj i međuinstitucijska suradnja.

Neke države procijenile su da je besmisleno samo zbog pitanja odgovornosti i kvalitete upravljanja te povezanosti javnog duga s drugim sektorima izdvajati javni dug iz Ministarstva financija. Naime u Francuskoj se dugo vodila rasprava oko toga treba li upravljanje javnim dugom izdvojiti iz Ministarstva financija, jer se smatralo da država nije samo financijski posrednik kojem treba određivati koju će tržišnu poziciju zauzeto, već da prioritet trebaju biti odnosni između upravljanja javnim dugom i javnih interesa. Rasprava u Francuskoj je završila tako da se osnovala Agencija za upravljanje javnim dugom koja je organizacijski unutar Državne riznice.

Kada se promatraju mogućnosti smanjenja troška zaduživanja postoji široko razumijevanje da široko i duboko primarno i sekundarno tržište pridonosi smanjivanju troška javnog duga. Prema tome nije iznenađenje da se pokušava održavati transparentno okruženje upravljanja javnim dugom. Kao rezultat toga moguće je uočiti da većina zemalja OECD-a ima vrlo slične procedure izdanja javnog duga (OECD, 2014).

\section{EKONOMSKO ZNAČENJE ZA MANJE RAZVIJENE EKONOMIJE}

Visoke razine fiskalnih deficita, visoke razine zaduženja i potreba za kontrolom rastućih rizika u servisiranju duga stvorile su potrebu za uspostavom kvalitetnijeg i efikasnijeg upravljanja javnim dugom. Bilance jedne manje razvijene ekonomije, kao što je Hrvatska, više su izložene vjerojatnosti financijskog udara nego neka visokorazvijena zemlja OECD-a (OECD, 2012). Razlog tome je manja baza domaćih $\mathrm{i}$ inozemnih investitora te slabije razvijen domaći financijski sustav. $U$ manje razvijenim ekonomijama otežano je dugoročno zaduživanje u domaćoj valuti, osim na kratki rok, dok se na dugi rok zaduženje provodi kroz obveznice koje su indeksirane na stranu valutu ili na inflaciju ili imaju zalog.

Osobine manje razvijenih ekonomija glede javnog duga su sljedeće:

- uloga koju ima Ministarstvo financija nije adekvatna, posebno zbog kapaciteta za vođenje javnog duga i formuliranja politika vođenja javnog duga;

- slaba je koordinacija između Ministarstva financija i središnje banke, što rezultira suboptimalnom harmonizacijom monetarne i fiskalne politike;

- middle office funkcija koja bi trebala provoditi analizu rizika ne postoji ili nije adekvatna;

- institucije za upravljanjejavnim dugom općenito imaju neadekvatan kadar i nisu u mogućnosti privući i zadržati visokokvalificiran kadar.

Zbog svega navedenog manje razvijene ekonomije osjetljiije su na pojavu financijske krize. Bilance i portfelji financijskih institucija u manje razvijenim ekonomijama uglavnom su tijesno povezane s državnim dugom, tako da se u slučaju krize generira i velik rizik za cjelokupnu ekonomiju. Jedan od važnih faktora je taj da u manje razvijenim ekonomija postoji niži stupanj neovisnosti u upravljanju 
javnim dugom od fiskalne politike. Dok nositelji fiskalne politike kontinuirano povećavaju deficite ili potencijalne obveze, efekt upravljanja javnim dugom vrlo je slab.

\section{UPRAVLJANJE JAVNIM DUGOM U REPUBLICI HRVATSKOJ}

U razdoblju od 2008. do 2015. javni dug Republike Hrvatske povećan je s 39,6 \% BDP-a na 86,7 \% BDP-a, odnosno s 137,6 milijardi kuna na 289,6 milijardi kuna. Na takav rast udjela javnog duga od 2008. utjecali su:

- proračunski deficiti u analiziranim godinama,

- zaduživanja poduzeća u državnom vlasništvu,

- $\quad$ pad BDP-a.

Grafikon 1. Kretanje javnog duga u Republici Hrvatskoj između 2008. i 2016. godine

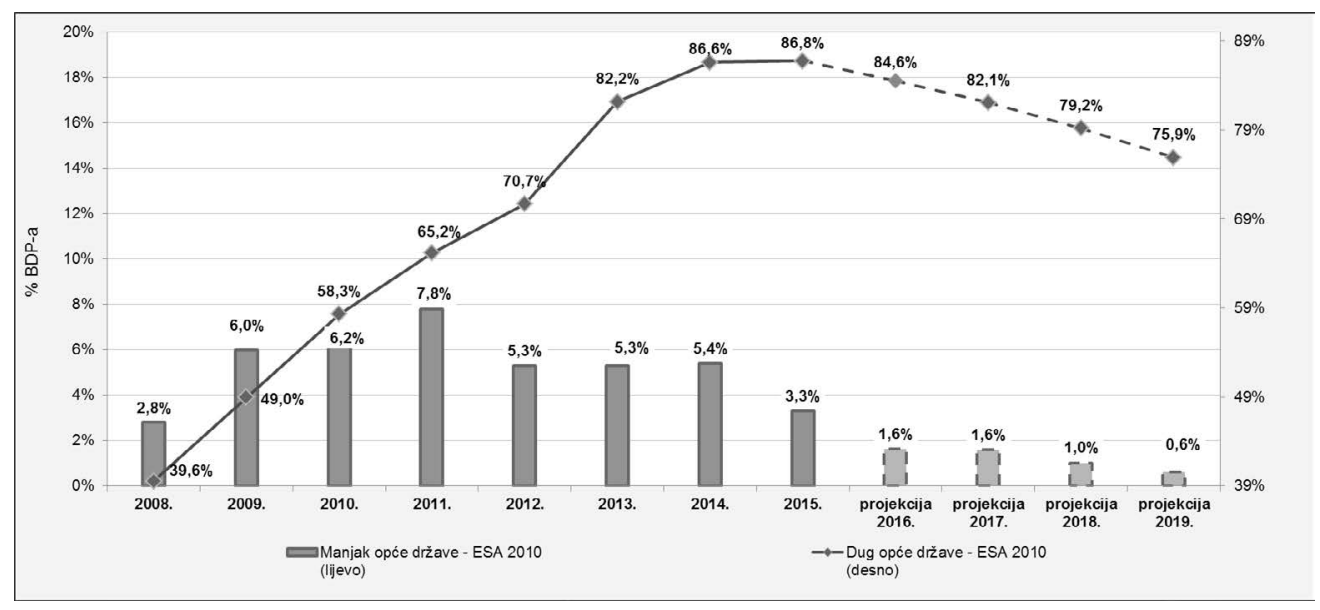

Izvor: Ministarstvo financija (2017)

U osnovi, trendovi pogoršanja javnog duga stabilizirali su se tijekom 2016. godine. Naime, tijekom 2016. godine zbog manjeg deficita volumen javnog duga je stagnirao, a BDP je značajnije rastao, što je dovelo do blagog pada pokazatelja javnog duga i BDP-a u odnosu na 2015. godinu.

Upravljanje javnim dugom nije zamjena za loše vođenje fiskalne politike, stoga i rezultati rada onih koji upravljaju javnim dugom ne mogu biti zadovoljavajući. Upravo iz tih razloga vrlo je teško provesti srednjoročnu strategiju upravljanja javnim dugom, pa loša i teška provedba strategije dovodi do toga da se strategija ne izrađuje niti objavljuje. Hrvatska je u tome poseban primjer gdje je iz Zakona o proračunu izbrisano da se izrađuje strategija i da se rade godišnja izvješća o javnom dugu. Veliki izazov za manje razvijene zemlje su plaće zaposlenih u Ministarstvu financija na upravljanju javnim dugom. Naime, plaće zaposlenih u Ministarstvu financija su značajno manje od onih u privatnom sektoru, pa postoje ogromni problemi u zapošljavanju stručnjaka s potrebnom razinom znanja. Kada se i uspije zaposliti zadovoljavajući kadar, Ministarstvo financija se suočava 
s drugim problemom, a to je kako zadržati zaposlene jer kada steknu iskustvo dobivaju ponude iz privatnog sektora gdje ih čekaju puno veće plaće.

Vezano uz primjere navedene u gornjim točkama implikacije za upravljanje javnim dugom u Republici Hrvatskoj bile bi kako slijedi:

- Institucijski okvir treba biti napravljan tako da omogući kvalitetno upravljanje javnim dugom, te efektivnu koordinaciju s monetarnom i fiskalnom politikom, uz permanentan razvoj domaćeg tržišta kapitala i nadzor stvaranja potencijalnih obveza. Sve ove funkcije mogu biti u upravi za javni dug unutar Ministarstva financija, ali unutar Ministarstva financija trebalo bi upravu za javni dug podići na visoku razinu po plaćama, bonusima i ostalim privilegijama zaposlenih koji upravljaju javnim dugom. Budući da sustav plaća i nagrađivanja državnih službenika ne podnosi takve "izolirane otoke" nužno je kreirati samostalnu instituciju za upravljanje javnim dugom, kao agenciju s posebnim ovlastima. $S$ time da treba naglasiti da tu instituciju treba osnovati Zakonom te ona ne bi trebala biti osnovana prema Zakonu o ustanovama. Kao što je već naglašeno, sustav plaća u instituciji za upravljanje javnim dugom treba biti baziran na nagrađivanju, tako da postoji poticaj da se zaposle visokokvalificirani stručni kadrovi i da žele ostati na tom poslu. S druge strane, ostali zaposlenici u državnom sektoru ne bi se osjećali manje vrijednim jer bi sustav nagrađivanja bio vezan uz uspješnost upravljanja javnim dugom.

- Treba dalje inzistirati na zaduživanju na domaćem tržištu, čime će se omogućiti daljnji razvoj domaćeg financijskog tržišša.

- Treba inzistirati na koordinaciji između Ministarstva financija i središnje banke, što bi trebalo rezultirati suboptimalnom harmonizacijom monetarne i fiskalne politike.

- Valja u procesima upravljanja javnim dugom zapošljavati iskusne zaposlenike sa specifičnim znanjima i upravljanja portfeljima i upravljanja rizicima.

- Treba razvijati procese upravljanja rizicima gdje će se postaviti rizični apetiti Države i strategije hedgiranja različitih rizičnih izloženosti koje nastaju pri upravljanju javnim dugom.

\section{ZAKLJUČAK}

Dužničke krize i globalna financijska kriza naglasile su važnost profesionalnog upravljanja javnim dugom te potrebu za efikasnim i likvidnim tržištem kapitala (IMF, 2014). Upravljanje javnim dugom podrazumijeva interakciju između javnog interesa i kompleksnih financijskih transakcija unutar strateškog okvira upravljanja rizikom, što sve zajedno predstavlja osnovu za izbor institucijskog okvira. U manje razvijenim tržǐstima ekonomija je više izložena financijskim šokovima i osjetljiva na krizu, što znači da treba veliku pažnju posvetiti smanjenju rizika. Institucijski okvir treba biti napravljan tako da omogući kvalitetno upravljanje javnim dugom te efektivnu koordinaciju s monetarnom i fiskalnom politikom, uz permanentan razvoj domaćeg tržišta kapitala i nadzor stvaranja potencijalnih obveza. Ponekad kreatori ekonomske politike ne razaznaju važnost reforme i poboljšanja upravljanja javnim dugom dok se ne pojavi kriza ili dug ne naraste na tako visoku razinu da je potrebno stvarati uštede na troškovima koji se plaćaju za servisiranje duga. 


\section{LITERATURA}

Bajo, A., Pezer, I. (2012) Strategije i ciljevi upravljanja javnim dugom. Zagreb: Riznica.

Currie, E., Dethier, J.-J., Togo, E. (2003) Institutional Arrangements for Public Debt Management. Washington: The World Bank.

IMF. (2014). Revised Guidelines for Public Debt Management. Washington: IMF.

IMF, WB. (2007) Strengthening Debt Management Practices: Lessons from Country Experiences and Issues Going Forward. Washington: International Monetary Fund and World Bank.

Ministartvo financija. (2017) Strategija upravljanja javnim dugom za razdoblje 2017. - 2019. Zagreb

OECD. (2012) OECD Sovereign Borrowing Outlook 2012. Paris: OECD.

OECD. (2014) OECD Sovereign Borrowing Outlook 2014. Paris: OECD.

Raspudić Golomejić, Z. (2007.) Koordinacija upravljanja javnim dugom i vođenja monetarne politike u Hrvatskoj. Financijska teorija i praksa 31, str. 151-179.

Švaljek, S., Andabaka Badurina, A. (2011) Public debt management before, during and after the crisis. Zagreb: IJF - Financial Theory and Practice.

Togo, E. (2007) Coordinating Public Debt Management with Fiscal and Monetary Policies: An Analytical Framework. Washington: The World Bank.

Weist, D., Togo, E., Prased, A., O’Boyle, W. (2010) Crisis Preparedness and Debt Management in Low Income Countries. Washington: The World Bank.

Wolswijk, G., de Haan, J. (2005) Government debt management in the Euro area - Recent theoretical developments and changes in practices. ECB Occasional Papers No. 25. 


\title{
INSTITUTIONAL FRAMEWORK FOR PUBLIC DEBT MANAGEMENT IN THE EU - WITH THE SPECIAL FOCUS ON CROATIAN CASE 3
}

\begin{abstract}
Public Debt Management for a long period plays an important role in the capital market, and the introduction of the euro and financial crisis have strengthened the role of institutions for public debt management. The aim is to show the importance of the institutional framework and the organization of the public debt. In Europe there is increased awareness of how necessary it is possible to become independent institutions for public debt management in order to ensure professionalism (in the management of extremely large state obligations which is especially important in times of crisis). Public debt management is important for the financial stability and institutional status should take into account all relevant factors of public debt as well as the objectives of public debt management, organization, debt holders, issuers of debt and debt trading practices. This paper mainly analyzes the institutional framework of public debt management. The concept analysis is based on a comparison of the institutional framework in the European Union. The debt crisis and the global financial crisis. stressed the importance of a professional debt management that can best be achieved by establishing an independent institution for public debt management. Policymakers are not always willing to reform and improve the management of public debt until the crisis or the debt has become unsustainable. The paper concludes that the choice of an independent institution for the management of public debt is in reality the best way for the successful management of public debt.
\end{abstract}

Key words: Public debt, debt crisis, capital markets

PhD, Senior Lecturer, Hrvatska narodna banka, Trga hrvatskih velikana 3, 10000 Zagreb, Croatia.

E-mail: ante.zigman@hnb.hr

2 PhD, Associate professor, Croatia banka d.d., R. F. Mihanovića 9, 10000 Zagreb, Croatia.

E-mail: ivan.sverko@croatiabanka.hr

3 Received: 9 December 2016; Accepted: 15 February 2017 